\title{
LATE SOWING AND NITROGEN APPLICATION TO OPTIMIZE CANOPY STRUCTURE AND GRAIN YIELD OF BREAD WHEAT IN A FLUCTUATING CLIMATE
}

\author{
Jia cheng ZHENG ${ }^{1}$, Hong ZHANG ${ }^{1}$, Jie YU ${ }^{1}$, Qiu wen $Z H A N^{1}$, Wen yang $L I^{1}$, Feng XU ${ }^{1}$, Guan jun \\ $W A N G^{3}$, Ting $L I U^{I^{*}}$ and Jin cai $L I^{2^{*}}$ \\ ${ }^{I}$ Anhui Science and Technology University, College of Agronomy, Feng yang, Anhui, P.R. CHINA \\ ${ }^{2}$ Anhui Agricultural University, National Engineering Laboratory of Crop Stress Resistance Breeding, \\ Changjiang West Road, He fei, Anhui, P.R. CHINA \\ ${ }^{3}$ Seed Administration Station of Yinshang County, Fuyang Anhui, P.R. CHINA \\ *Corresponding authors: zjcx_534@126.com; lijincai@ahau.edu.cn
}

Receiveed: 04.11.2020

\begin{abstract}
Adjustment of sowing date and nitrogen (N) use help alleviate farmland contradiction under fluctuating climate in Jianghuai region of China. In this study, two wheat varieties were used to study the interactive effect between two sowing dates and two basal to topdressing ratios of $N$ fertilizer, each treatment of eight combinations arranged in Randomized Complete Block Design (RCBD) with three replications was conducted in two consecutive growth seasons of bread wheat. As results of two years of investigation, wheat plants with an excessively delayed sowing date showed a significant reduction in flag leaf angle, flag leaf area, main stem spike length and photosynthesis rate, yet a increased basic seedling number and transpiration rate, which corresponded to a notable loss in thousand kernel weight and grain yield. An increase in the proportion of topdressed $\mathrm{N}$ led to an increase in flag leaf angle and leaf area index, and a lower spike number per unit and thousand kernel weight, to indicate a loss of grain yield. These findings suggest that excessively delayed sowing date and high $\mathrm{N}$ topdressing ratios severely affected the canopy structure and thousand kernel weight of bread wheat, and subsequently reduced grain yield. Based on membership function analysis, a sowing date of 25 October coupled with the $N$ topdressing ratio of 7:3 (the basal to topdressing ratios of $N$ fertilizer) was the ideal combination to optimize the wheat industry in Jianghuai region of China.
\end{abstract}

Key words: Canopy structure, grain yield, $\mathrm{N}$ application, sowing date, wheat

\section{INTRODUCTION}

Wheat is one of the most important grain crops in the world and holds the second-largest position in the Chinese crop production (Song et al., 2017). Currently, there exists an increase in demand for food due to exponential population and different consumption habits, and the unavailability of arable land exacerbates the production-demand dynamic (Kucharik et al., 2020). The only feasible strategy is to continually improve grain yield per unit area (GY), and thus satisfy population demand and ensure food security (Ayranci, 2020). The Anhui province, located within a transitional zone between the subtropics and warm temperate climate, ranks fourth nationally as a crop-growing region and employs the double cropping system of either wheat-maize or wheatrice. However, an uneven distribution of resources and the fluctuating climate system (i.e., late spring coldness, wheat water logging) can severely limit wheat production (Herrera et al., 2020; Lu et al., 2020).
Nitrogen (N) supplementation is a vital factor in augmenting crop yields and securing global food security. Proper time, basal to topdressing ratio, and nitrogen utilization efficiency (NUE) significantly impact wheat yield and grain quality (Guo et al., 2019; Zorb et al., 2018). Appropriate sowing time of wheat is conducive to producing an ideal canopy structure and to coordinate the development of yield-related traits, leading to an increased wheat production (Ma et al., 2018). However, excessive $\mathrm{N}$ use and unreasonable $\mathrm{N}$ application can greatly reduce NUE, induce adverse ecological pressures, and push against the fertilizer and green development strategies of China (Gourevitch et al., 2018; Tilman et al., 2011). An inappropriate sowing time can cause excessive or sluggish growth of wheat at an early development stage, which might establish unbalanced population structure in later stages and result in less stress resistance and a decrease in yield and quality (Gorczyca et al., 2017). Selecting the optimal criterion of $\mathrm{N}$ application and sowing date is a 
crucial process to improve population structure and grain yield of wheat in a fluctuating climate.

Extensive research has been conducted on wheat photosynthesis, NUE and grain yield under $\mathrm{N}$ application, as well as effect of sowing time on metabolism of carbon and $\mathrm{N}$, accumulation and distribution of dry matter (Zorb et al., 2018; Ahmed et al., 2015). In recent years, the watchful delay in harvesting rice and maize has been encouraged to increase production in China, whereas the optimal criterion of late sowing and $\mathrm{N}$ basal to topdressing ratio in wheat was cursorily addressed in the Jianghuai region. In this study, popular wheat varieties in Jianghuai region were used to investigate the interactive effect between sowing time and $\mathrm{N}$ basal to topdressing ratio, as this interaction might clarify their combined impact on wheat canopy structure, photosynthesis system, and yield-related traits in a fluctuating climate. The common cultured system with high production and elevated efficiency in wheat farming were concluded to apply and widely practice in the Jianghuai region.

\section{MATERIALS AND METHODS}

\section{Materials and experimental design}

The experiment was conducted during two growth seasons of winter wheat (October to June of 2018-2019 and 2019-2020) at the national modern agriculture demonstration station in the Hong xing town, Ying shang County, Anhui Province, China $\left(116.0^{\circ} \mathrm{E}, 32.7^{\circ} \mathrm{N}\right)$. Climatic data was measured everyday in local meteorological station. The crop field has a Sha jiang black soil (organic matter $24.3 \mathrm{~g} \cdot \mathrm{kg}^{-1}$, total nitrogen $0.11 \%$, available phosphorus $9.5 \mathrm{mg} \cdot \mathrm{kg}^{-1}$, available potassium $\left.281 \mathrm{mg} \cdot \mathrm{kg}^{-1}\right)$, with the straw from maize of previous cropping seasons crushed and scattered across the field after harvesting.

Varieties Jimai22 (G1) and Yannong5286 (G2) (both of semi-winter wheat) were sown on either 25 October (D1) or 15 November (D2), with fertilization of pure nitrogen $180 \mathrm{~kg} \cdot \mathrm{ha}^{-1}, \mathrm{P}_{2} \mathrm{O}_{5} 120 \mathrm{~kg} \cdot \mathrm{ha}^{-1}$ and $\mathrm{K}_{2} \mathrm{SO}_{4} 120$ $\mathrm{kg} \cdot \mathrm{ha}^{-1}$. Phosphate and potash were applied together as base fertilizers, and $\mathrm{N}$ fertilizer was used at two levels applied at the basal and jointing stages (Z31) (Zadoks et al., 1974) for different basal to topdressing ratios $(60 \%$ basal $\mathrm{N}$ to $40 \%$ topdressing [6:4, N1], $70 \%$ basal $\mathrm{N}$ to $30 \%$ topdressing [7:3, N2]). Each treatment combination (D1N1G1， D1N1G2，D1N2G1，D1N2G2，D2N1G1, D2N1G2, D2N2G1, and D2N2G2) was replicated for three times. Wheat seeds were sown by mechanized drill with an row spacing of $25 \mathrm{~cm}$, as well as seeding rate of $210 \mathrm{~kg} \cdot \mathrm{ha}^{-1}, 120 \mathrm{~m}^{2}$ area for each plot. Field management was processed for high yield and good quality in the local region.

\section{Measurement of agronomic traits}

Prior to the overwintering period, the number of basic seedlings and tillers of wheat were recorded at the seedling stage (Z25) (Zadoks et al., 1974). At the grain-filling stage (Z73), plant height $(\mathrm{PH})$, flag leaf area and angle (FLA and FLAN), and spike number per unit (SN) were measured (Zheng et al., 2015), and leaf area index (LAI) was estimated by the instrument of LAI meter (FRANKE, FK-G10, China), as well as measurement of photosynthetic rate (A), stomatal conductance (gs), transpiration rate $(\mathrm{E})$ and intercellular $\mathrm{CO}_{2}$ concentration (Ci) on flag leaf by photosynthesis system (LI-6400, USA). After harvest (Z94), main stem spike length (MSSL), main stem spike spikelet number (MSSSN), main stem spike grain number (MSSGN), sterile spikelet number (SSN), thousand kernel weight (TKW) and grain yield (GY) were investigated, as well as determination of grain quality by the infrared grain analyzer (perten DA7200, Sweden), including six quality indexes of protein content (PC), volume weight (VW), wet gluten content (WGC), stability time (ST), development time (DT), hardness index (HI), sedimentation value (SV) and flour yield (FY). Five replicates of each plot were set to evaluate the agronomic traits during two growth seasons.

\section{Data analysis}

The flag leaf area was calculated according to the method of Zheng et al. (2015). The agronomic traits under different treatments were evaluated by principal component analysis (SPSS 18.0 software) to obtain the coefficient of principal component and calculate its comprehensive value and subordinative function indexes. The formula was as follows:

$$
u\left(X_{j}\right)=\frac{\left(X_{j}-X_{\min }\right)}{\left(X_{\max }-X_{\min }\right)} \quad j=1,2, \ldots, n
$$

Where $X_{j}$ was the $j$-th comprehensive index, and $X_{\min }$ and $X_{\max }$ were the minimum and maximum of the $j$-th comprehensive index, respectively.

The weight formula of comprehensive index was used:

$$
\omega_{j}=\frac{p_{j}}{\sum_{j=1}^{n} p_{j}}
$$

Where $\omega_{j}$ was the weight, and $\mathrm{p}_{j}$ was the contribution rate of the $j$-th comprehensive index under different treatments.

Value $D$, the overall effect of different treatments on the agronomic traits of wheat, was assessed as follows:

$$
D=\sum_{j=1}^{n}\left[u\left(X_{j}\right) \mathrm{w}_{j}\right] \quad j=1,2, \ldots, n
$$

All the data and diagramming were processed using Microsoft Excel 2010. Variance analysis was conducted with SPSS 18.0, as well as the cluster analysis on different treatments, based on the agronomic traits.

\section{RESULTS AND DISCUSSION}

Climate fluctuation and late spring coldness during wheat development 
In relation to genetic variation, the traits, such as $\mathrm{PH}$, FLA, SN, MSSGN etc., were significantly affected by climate fluctuation in the field (Aljarrah et al., 2014; Ahmed et al., 2015). After wheat planting, the average temperature during wintering period was $4.2^{\circ} \mathrm{C}$ and $6.2^{\circ} \mathrm{C}$ in December of 2018 and 2019 (Z14 to Z22), and $2.6^{\circ} \mathrm{C}$ and $3.0^{\circ} \mathrm{C}$ in January of 2019 and 2020 (Z23 to Z29), respectively (Figure1), which can support the smoothly overwintering for semi-winter wheat varieties in Jianghuai region of China. However, the seedlings suffered from the lower field temperature in mid-February during wheat returning-green stage (Z31): in 2019, the average temperature below $4^{\circ} \mathrm{C}$ lasted for 8 days, with the lowest temperature of $-1{ }^{\circ} \mathrm{C}$, and the lower temperature lasted for 5 days, with the lowest temperature of $-3^{\circ} \mathrm{C}$ in 2020 , the disastrous weather enable young seedling suffer from late spring coldness, hinder the early differentiation and develop the poorly basic population structure (Zheng et al., 2020a). At stage of wheat stem starting to elongate on both from March 9 to 14 and from March 27 to 31, the field temperature dropped sharply again with an average minimum temperature of $6.0^{\circ} \mathrm{C}$ and $7.0^{\circ} \mathrm{C}$ in 2019 , and $4.7^{\circ} \mathrm{C}$ and $5.2^{\circ} \mathrm{C}$ in 2020 , respectively, along with a durative-moderate rain in 2020. Under cold stress, some plants showed cold damage (e.g., yellow leaf tips, droop leaves, less tillers), which seriously affected the wheat structure formulation in the field. Therefore, it is necessary to manage the wheat colony structure at the pre-wintering period and circumvent the adversity of spring coldness.

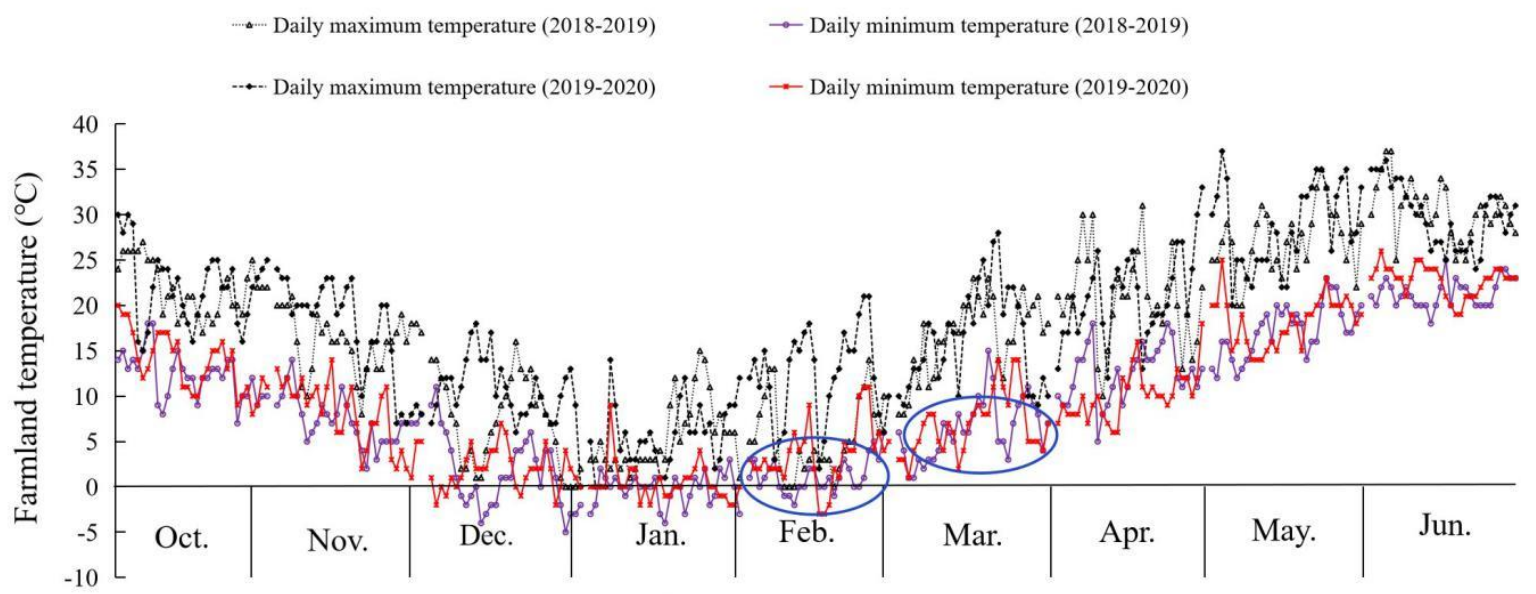

Wheat development stages

Figure1. Temperature distribution during the wheat-growing period in the year of 2018-2019 and 2019-2020

\section{Genetic variation analysis of agronomic traits under different treatments}

After two growth seasons of treatment, the colony structure and yield-related traits of wheat were investigated to explore the genetic variation (Table 1). The results revealed that there were significant differences $(P<0.05)$ in $\mathrm{PH}, \mathrm{SN}$, and GY between the two seasons, whereas the greatly significant differences $(P<0.01)$ in most agronomic traits (TN, PH, FLA, FLAN, MSSL, MSSSN, SSN, SN, TKW and GY) under treatment of sowing date. Different basal to topdressing ratios of nitrogen displayed the greatest significant differences $(P<0.01)$ in PH, FLA, FLAN and SN, and only the significant differences $(P<0.05)$ in SSN and TKW. Further multiple comparisons showed the greatly significant differences of PH, FLA, FLAN and MSSL between two cultivars $(P<0.01)$, as well as the considerable variations for the respective agronomic traits except for basic seedling number (BSN), tiller number (TN), LAI and MSSGN within the four interaction factors. 
Table 1. Analysis of variance (ANOVA) of the agronomic traits investigated in two growth seasons of bread wheat

\begin{tabular}{|c|c|c|c|c|c|c|c|c|c|c|c|c|c|c|}
\hline MS & df & $\begin{array}{c}\text { BSN } \\
\left.\text { (ten thousand } \cdot h^{-1}\right)\end{array}$ & $\begin{array}{c}\text { TN } \\
\text { (No.) }\end{array}$ & $\begin{array}{c}\text { PH } \\
(\mathbf{c m})\end{array}$ & $\begin{array}{l}\text { FLA } \\
\left(\mathrm{cm}^{2}\right) \\
\end{array}$ & LAI & $\begin{array}{c}\text { FLAN } \\
\left({ }^{\circ}\right)\end{array}$ & $\begin{array}{c}\text { MSSL } \\
(\mathrm{cm})\end{array}$ & $\begin{array}{c}\text { MSSSN } \\
\text { (No.) }\end{array}$ & $\begin{array}{c}\text { MSSGN } \\
\text { (No.) }\end{array}$ & $\begin{array}{l}\text { SSN } \\
\text { (No.) }\end{array}$ & $\begin{array}{c}\text { SN } \\
\left.\left(\text { ten thousand } \cdot h^{-1}\right)^{-1}\right)\end{array}$ & $\begin{array}{c}\text { TKW } \\
(\mathrm{g})\end{array}$ & $\begin{array}{c}\text { GY } \\
\left(\mathbf{M T} \cdot \mathbf{h a}^{-1}\right)\end{array}$ \\
\hline Year (Y) & 1 & 0.20 & 0.38 & $53.47^{*}$ & 17.11 & 0.49 & 13.20 & 0.14 & 0.80 & 53.39 & 0.00 & $0.02^{*}$ & 1.73 & $1.42^{*}$ \\
\hline Data（D） & 1 & $1692.00^{*}$ & $12.04^{* *}$ & $235.99^{* *}$ & $209.95^{* *}$ & 0.48 & $200.03^{* *}$ & $23.87^{* *}$ & $54.45^{* *}$ & 10.69 & $9.80^{* *}$ & $10.73^{* *}$ & $576.16^{* *}$ & $22754.79^{* *}$ \\
\hline Nitrogen $(\mathrm{N})$ & 1 & 20.56 & 0.30 & $125.00^{* *}$ & $124.00^{* *}$ & 2.35 & $126.25^{* *}$ & 1.71 & 0.10 & 15.45 & $3.20^{*}$ & $10.53^{* *}$ & $69.36^{*}$ & 1540.58 \\
\hline Genotype (G) & 1 & 0.60 & 0.38 & $71.82^{* *}$ & $359.55^{* *}$ & 0.65 & $73.15^{* *}$ & $15.40^{* *}$ & 0.20 & 10.69 & 0.45 & $3.27^{*}$ & 43.51 & 1687.61 \\
\hline $\mathrm{Y} \times \mathrm{D} \times \mathrm{N} \times \mathrm{G}$ & 7 & 246.30 & 1.91 & $76.64^{* *}$ & $104.23^{* *}$ & 0.56 & $58.68^{* *}$ & $6.09^{* *}$ & $10.14^{* *}$ & 13.47 & $3.45^{* *}$ & $4.14^{* *}$ & $101.64^{* *}$ & $3888.45^{* *}$ \\
\hline Error & 88 & 319.00 & 1.08 & 4.09 & 2.66 & 3.47 & 2.10 & 0.13 & 0.99 & 360.40 & 0.21 & 0.27 & 0.45 & 15.21 \\
\hline $\mathrm{F}$ & & 0.77 & 1.77 & 18.73 & 39.14 & 0.16 & 27.94 & 45.39 & 10.28 & 0.04 & 16.13 & 15.58 & 224.84 & 0.26 \\
\hline
\end{tabular}

Note: df was degrees of freedom, BSN was the basic seedling number, TN was the tiller number, PH was the plant height, FLA was the flag leaf area, LAI was the leaf area index, FLAN was the flag leaf angle, MSSL was the main stem spike length, MSSSN was the main stem spike spikelet number, MSSGN was the main stem spike grain number, SSN was the sterile spikelet number, SN was the spike number per unit, TKW was the thousand kernel weight, GY was the grain yield. ${ }^{*}$ and ${ }^{* *}$ indicate significance at the $P<0.05$ and $P<0.01$ levels (Duncan), respectively.

\section{Effects of sowing date and nitrogen application on colony structure}

Crop colony structure exhibit the visualized population size, growth distribution, field performance and dynamic change of individual plants, which directly affects the development of yield-related components. In this study, for the two growth seasons (Table 2), in a comparison of the D1 sowing date vs. the delayed D2 sowing date, the BSN was significantly increased alongside a decrease in FLAN and FLA $(P<0.05)$, resulting in the reduced LAI. When cultivars within the same sowing date were treated with N2 vs the larger topdressing ratio of $\mathrm{N} 1$, they showed an increase in BSN and $\mathrm{PH}$, but a decrease in FLAN, FLA, and LAI. For the D1 sowing date, the wheat plants displayed loose and excellent colony structure, and showed the maximum FLAN and FLA in the group of D1N1G1 and D1N1G2, respectively, with average data of $27.3^{\circ}$ and $33.0 \mathrm{~cm}^{2}$ over the two growth seasons. Within the same sowing date (D) and the same cultivar (G), when comparing N1 wheat groups, the FLAN was significantly reduced in N2 groups, as well as the FLA in the variety G2 groups only $(P<0.05)$ The N1 application, could improve LAI, exemplified through the D1N1G1 treatment group where the LAI reached an average of 5.1 in the two growth seasons. Appropriate postponing sowing date could effectively manage the wheat colony structure at the pre-wintering period, and the study demonstrated that excessively late sowing date had a significant negative effect on leaf canopy structure, which was agreed with the report (Barraclough and Leigh, 1984).

Table 2. Colony structure traits based on the treatments of sowing date and nitrogen applications

\begin{tabular}{|c|c|c|c|c|c|c|c|c|c|}
\hline \multirow{2}{*}{ Traits } & \multirow{2}{*}{ Season } & \multicolumn{8}{|c|}{ Treatments } \\
\hline & & D1N1G1 & D1N1G2 & D1N2G1 & D1N2G2 & D2N1G1 & D2N1G2 & D2N2G1 & D2N2G2 \\
\hline \multirow{2}{*}{$\begin{array}{c}\text { BSN } \\
\text { (ten thousand } \cdot \mathrm{ha}^{-1} \text { ) }\end{array}$} & 2018-2019 & $288.1 \pm 20.7 \mathrm{a}$ & $281.1 \pm 6.6 \mathrm{a}$ & $290.1 \pm 2.6 \mathrm{a}$ & $300.2 \pm 3.3 \mathrm{a}$ & $412.2 \pm 1.6 \mathrm{~b}$ & $403.2 \pm 30.0 \mathrm{~b}$ & $426.2 \pm 25.4 \mathrm{~b}$ & $422.2 \pm 18.6 b$ \\
\hline & $2019-2020$ & $295.1 \pm 21.8 \mathrm{a}$ & $280.1 \pm 7.1 \mathrm{a}$ & $296.1 \pm 8.4 \mathrm{a}$ & $301.2 \pm 4.4 \mathrm{a}$ & $412.2 \pm 9.9 b$ & $401.2 \pm 28.9 \mathrm{~b}$ & $425.2 \pm 13.7 \mathrm{~b}$ & $430.2 \pm 18.3 b$ \\
\hline \multirow{2}{*}{ TN (No.) } & 2018-2019 & $5 \pm 1 \mathrm{a}$ & $5 \pm 1 \mathrm{a}$ & $5 \pm 1 \mathrm{a}$ & $5 \pm 1 \mathrm{a}$ & $4 \pm 1 \mathrm{a}$ & $4 \pm 0 \mathrm{a}$ & $4 \pm 0 \mathrm{a}$ & $4 \pm 0 \mathrm{a}$ \\
\hline & $2019-2020$ & $5 \pm 0 \mathrm{bc}$ & $5 \pm 0 \mathrm{c}$ & $5 \pm 0 \mathrm{c}$ & $5 \pm 0 \mathrm{bc}$ & $4 \pm 0 \mathrm{a}$ & $4 \pm 0 \mathrm{a}$ & $4 \pm 0 \mathrm{a}$ & $4 \pm 0 \mathrm{a}$ \\
\hline \multirow{2}{*}{$\mathrm{PH}(\mathrm{cm})$} & 2018-2019 & $83.5 \pm 0.5 \mathrm{a}$ & $85.4 \pm 0.6 b$ & $85.8 \pm 0.7 b$ & $90.1 \pm 1.5 \mathrm{c}$ & $81.4 \pm 0.4 \mathrm{a}$ & $82.7 \pm 1.5 \mathrm{ab}$ & $83.6 \pm 1.0 \mathrm{ab}$ & $82.9 \pm 0.7 \mathrm{ab}$ \\
\hline & $2019-2020$ & $84.5 \pm 0.6 \mathrm{a}$ & $87.2 \pm 0.4 b$ & $87.0 \pm 1.0 \mathrm{~b}$ & $92.4 \pm 0.6 \mathrm{c}$ & $83.6 \pm 1.0 \mathrm{a}$ & $83.8 \pm 0.4 \mathrm{a}$ & $85.2 \pm 1.1 \mathrm{ab}$ & $85.2 \pm 0.4 \mathrm{ab}$ \\
\hline \multirow{2}{*}{$\operatorname{FLAN}\left({ }^{\circ}\right)$} & 2018-2019 & $26.8 \pm 0.4 \mathrm{e}$ & $24.6 \pm 0.4 \mathrm{~d}$ & $23.4 \pm 0.8 \mathrm{~cd}$ & $22.4 \pm 0.4 \mathrm{bc}$ & $23.4 \pm 0.5 \mathrm{~cd}$ & $21.8 \pm 0.6 \mathrm{bc}$ & $19.4 \pm 1.2 \mathrm{a}$ & $20.5 \pm 0.4 \mathrm{a}$ \\
\hline & 2019-2020 & $27.7 \pm 0.1 \mathrm{e}$ & $25.4 \pm 0.4 \mathrm{~d}$ & $25.2 \pm 0.5 \mathrm{~d}$ & $23.0 \pm 0.2 \mathrm{c}$ & $25.2 \pm 0.4 \mathrm{~d}$ & $21.0 \pm 0.4 \mathrm{~b}$ & $22.4 \pm 0.9 \mathrm{c}$ & $19.2 \pm 0.4 \mathrm{a}$ \\
\hline \multirow{2}{*}{ FLA $\left(\mathrm{cm}^{2}\right)$} & 2018-2019 & $27.8 \pm 0.3 \mathrm{bc}$ & $32.6 \pm 0.6 \mathrm{e}$ & $25.7 \pm 0.7 b$ & $30.2 \pm 0.5 \mathrm{~cd}$ & $25.2 \pm 0.9 \mathrm{a}$ & $30.0 \pm 0.8 \mathrm{~cd}$ & $22.8 \pm 1.2 \mathrm{a}$ & $25.8 \pm 1.4 \mathrm{~b}$ \\
\hline & 2019-2020 & $28.5 \pm 0.3 \mathrm{c}$ & $33.3 \pm 0.4 \mathrm{e}$ & $26.9 \pm 0.3 b$ & $31.7 \pm 0.9 \mathrm{~d}$ & $25.3 \pm 0.4 \mathrm{a}$ & $31.1 \pm 0.4 \mathrm{~d}$ & $24.7 \pm 0.7 \mathrm{a}$ & $26.0 \pm 0.4 \mathrm{ab}$ \\
\hline \multirow{2}{*}{ LAI } & 2018-2019 & $5.0 \pm 0.1 \mathrm{c}$ & $4.5 \pm 0.1 \mathrm{~b}$ & $4.5 \pm 0.2 b$ & $4.3 \pm 0.2 \mathrm{ab}$ & $4.6 \pm 0.1 \mathrm{~b}$ & $4.2 \pm 0.1 \mathrm{ab}$ & $4.3 \pm 0.1 \mathrm{ab}$ & $4.0 \pm 0.0 \mathrm{a}$ \\
\hline & 2019-2020 & $5.2 \pm 0.1 \mathrm{e}$ & $4.7 \pm 0.0 \mathrm{~d}$ & $4.6 \pm 0.1 \mathrm{~cd}$ & $4.4 \pm 0.1 \mathrm{bc}$ & $4.7 \pm 0.1 \mathrm{~d}$ & $4.3 \pm 0.0 \mathrm{ab}$ & $4.4 \pm 0.0 \mathrm{bc}$ & $4.1 \pm 0.1 \mathrm{a}$ \\
\hline
\end{tabular}

Note: Values were represented as means \pm s.e. $(\mathrm{n}=15)$, lowercase letters indicated the significant difference among different treatments in the same row $(P<0.05)$. Letter $\mathrm{D}, \mathrm{N}$, and $\mathrm{G}$ were the treatments of sowing date, $\mathrm{N}$ basal to topdressing ratios and wheat varieties, respectively. BSN was the basic seedling number, TN was the tiller number, PH was the plant height, FLAN was the flag leaf angle, FLA was the flag leaf area, LAI was the leaf area index. 


\section{Regulation of sowing date and nitrogen application on photosynthetic-related traits}

The photosynthesis rate (A) contributed more than $80 \%$ to grain growth during the later development period, and there was a significant positive correlation between canopy photosynthetic rate (CAP) and GY (Mantilla-Perez et al., 2017). Topdressing of $\mathrm{N}$ fertilizer during the jointing-booting period could prolong the function stages of flag-leaf, increase the A index after the flowering stage, promote the accumulation of dry matter (Nehe et al., 2018; Ma et al., 2019). Here, at the grain-filling stage (Figure2), photosynthetic-related traits showed that the delayed D2 sowing date group displayed a significant decrease in A and $\mathrm{Ci}$ index alongside a significant increase in $\mathrm{g}_{\mathrm{s}}$ and $\mathrm{E}$ index, an exception was $\mathrm{g}_{\mathrm{s}}$ between D1N2G1 and D2N2G1 when compared to the corresponding treatment on the D1 sowing date $(P<0.05)$. Even with two nitrogen applications, wheat from the same sowing date (D) and cultivar $(G)$ showed no significant difference in A index. On the D1 sowing date, groups with the same cultivar showed significantly higher $g_{s}$ with $\mathrm{N} 2$ treatment compared to N1. During D1 treatment with the same cultivar $\mathrm{G}$, the $\mathrm{E}$ index under $\mathrm{N} 2$ treatment was significantly higher than the N1. In each of D1 and D2 sowing date groups, the same cultivar subjected to N1 treatment showed significantly higher $\mathrm{C}_{\mathrm{i}}$ index than $\mathrm{N} 2$ in both years.
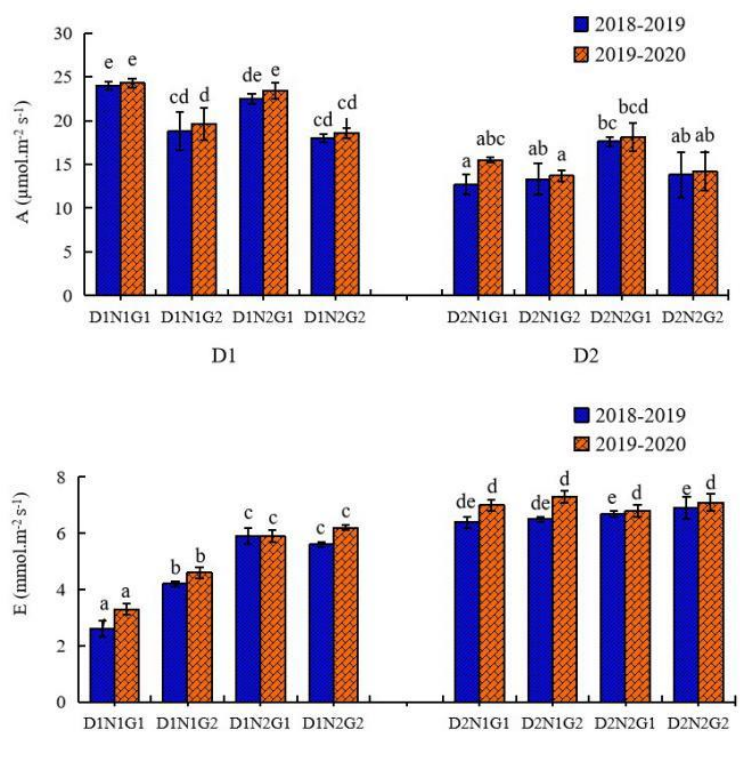

D1

D2

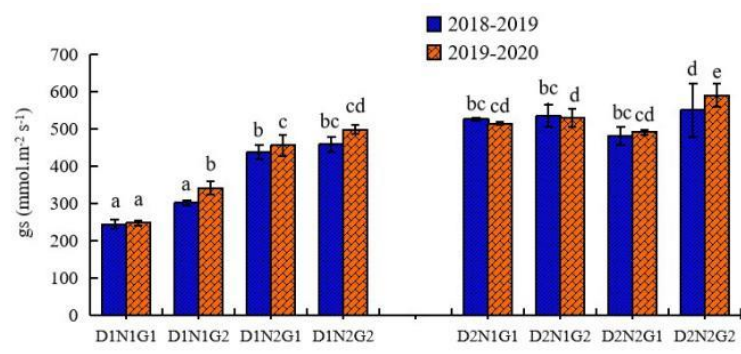

D1

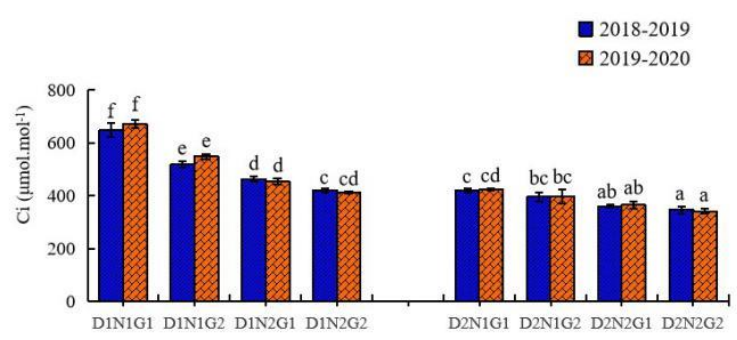

D1

Figure2. Photosynthesis-related traits of bread wheat under sowing date and nitrogen application.

Note: Values were represented as means \pm s.e. $(n=15)$, lowercase letters indicated the significant difference among different treatments in the same wheat growth season $(P<0.05)$. A was the photosynthetic rate, $\mathrm{g}_{\mathrm{s}}$ was the stomatal conductance, $\mathrm{E}$ was the transpiration rate, and $\mathrm{Ci}$ was the intercellular $\mathrm{CO}_{2}$ concentration.

\section{Effects of sowing date and nitrogen application on yield-related traits}

Multiple yield-related factors coordinately contribute on the formation of grain yield. In wheat, appropriate increase of $\mathrm{N}$ application was conducive to tillering and spike development, improvement of SN, MSSGN and TKW, together leading to the enhanced GY (Zheng et al., $2020 \mathrm{~b}$ ). After the determination of $\mathrm{N}$ fertilizer, postponing $\mathrm{N}$ application could delay the senescence of leaves and roots in wheat, and thus promote grain filling alongside the increased GY (Nehe et al., 2018). Here, the slightly late sowing date (D1) showed the better phenotype, whereas for one month later (D2), the population density was excessively high, leading to significantly decreased $\mathrm{PH}$ and weakened photosynthetic capacity, which was not conducive for successful yield formation. As shown in
Table 3, compared to the corresponding treatment on the delayed D2 sowing date, the D1 group showed a significant increase in MSSL, TKW and GY, alongside a significant decrease in MSSSN and SSN under either D1N1G2 or D1N2G2, and SN under D1N2G1. Within the same sowing date, the N2 treatment, which has a less substantial application proportion referring to $\mathrm{N} 1$, demonstrated a significant increase in TKW, and the upward trend in MSSL, SN and GY for the same cultivar. In the D1N2G2 treatment groups, TKW continuously reached the maximum index, and generating the highest GY in both years (average $9251.6 \mathrm{~kg} \cdot \mathrm{ha}^{-1}$ ). D1 treatment with the same cultivar showed an increase in GY with the $\mathrm{N} 2$ treatment compared to the N1 treatment. To a certain amount of $\mathrm{N}$ fertilizer, the results suggested that the increase ratio of $\mathrm{N}$ topdressing application enlarged LAI, whereas MSSL, TKW and SN decreased, producing a 
reduced yield, implicating that sufficiently basal $\mathrm{N}$ fertilizer ensured excellent colony structure, high ability of tillering and spike rate, and appropriate topdressing ratio at late developmental stage enhanced TKW, promoting yield in wheat. Conversely, excessive postponing $\mathrm{N}$ application may induce crazy growth, interfere grain filling process, and decrease GY. TKW was the significantly correlated with yield-related traits $(\mathrm{r}=$ 0.92), and grain formation and grain-filling dynamics are required to determine the regulation mechanism of TKW affected by sowing time and nitrogen application.

Table 3. Effects of sowing stage and nitrogen application on yield-related traits of wheat

\begin{tabular}{|c|c|c|c|c|c|c|c|c|c|}
\hline \multirow{2}{*}{ Traits } & \multirow{2}{*}{ Season } & \multicolumn{8}{|c|}{ Treatments } \\
\hline & & D1N1G1 & D1N1G2 & D1N2G1 & D1N2G2 & . D2N1G1 & D2N1G2 & D2N2G1 & D2N2G2 \\
\hline \multirow{2}{*}{$\begin{array}{l}\text { MSSL } \\
(\mathrm{cm})\end{array}$} & $2018-2019$ & $10.0 \pm 0.1 \mathrm{~d}$ & $9.1 \pm 0.0 \mathrm{bc}$ & $10.7 \pm 0.2 \mathrm{e}$ & $9.4 \pm 0.1 \mathrm{c}$ & $8.9 \pm 0.1 b$ & $8.3 \pm 0.1 \mathrm{a}$ & $9.2 \pm 0.1 \mathrm{bc}$ & $8.6 \pm 0.2 \mathrm{a}$ \\
\hline & $2019-2020$ & $10.4 \pm 0.2 \mathrm{c}$ & $9.2 \pm 0.1 \mathrm{~b}$ & $10.6 \pm 0.4 \mathrm{~d}$ & $9.5 \pm 0.3 b$ & $9.0 \pm 0.1 \mathrm{ab}$ & $8.4 \pm 0.1 \mathrm{a}$ & $9.2 \pm 0.1 \mathrm{~b}$ & $8.5 \pm 0.1 \mathrm{a}$ \\
\hline \multirow{2}{*}{$\begin{array}{l}\text { MSSSN } \\
\text { (No.) }\end{array}$} & $2018-2019$ & $20 \pm 0 \mathrm{abc}$ & $19 \pm 0 \mathrm{ab}$ & $20 \pm 0 \mathrm{abc}$ & $19 \pm 0 \mathrm{a}$ & $21 \pm 0 \mathrm{bcd}$ & $22 \pm 0 \mathrm{e}$ & $21 \pm 1$ cde & $22 \pm 1 \mathrm{de}$ \\
\hline & 2019-2020 & $20 \pm 0 \mathrm{ab}$ & $20 \pm 0 \mathrm{a}$ & $20 \pm 0 \mathrm{ab}$ & $19 \pm 1 \mathrm{a}$ & $20 \pm 1 \mathrm{ab}$ & $22 \pm 1 b$ & $22 \pm 1 b$ & $22 \pm 1 b$ \\
\hline \multirow{2}{*}{$\begin{array}{l}\text { MSSGN } \\
\text { (No.) }\end{array}$} & $2018-2019$ & $48 \pm 2 b$ & $45 \pm 1 \mathrm{ab}$ & $47 \pm 1 b$ & $46 \pm 1 \mathrm{ab}$ & $46 \pm 1 \mathrm{ab}$ & $42 \pm 2 \mathrm{a}$ & $45 \pm 1 \mathrm{ab}$ & $44 \pm 1 \mathrm{ab}$ \\
\hline & $2019-2020$ & $50 \pm 1 \mathrm{~d}$ & $45 \pm 1 \mathrm{abc}$ & $47 \pm 1 \mathrm{bcd}$ & $48 \pm 1 \mathrm{~cd}$ & $47 \pm 1 \mathrm{bcd}$ & $43 \pm 1 \mathrm{a}$ & $45 \pm 1 \mathrm{abc}$ & $44 \pm 1 \mathrm{ab}$ \\
\hline \multirow{2}{*}{$\begin{array}{l}\text { SSN } \\
\text { (No.) }\end{array}$} & 2018-2019 & $1 \pm 0 \mathrm{a}$ & $1 \pm 0 \mathrm{a}$ & $2 \pm 0 \mathrm{c}$ & $1 \pm 0 \mathrm{ab}$ & $1 \pm 0 \mathrm{ab}$ & $2 \pm 0 \mathrm{c}$ & $2 \pm 0 \mathrm{bc}$ & $2 \pm 0 \mathrm{c}$ \\
\hline & $2019-2020$ & $1 \pm 0 \mathrm{a}$ & $1 \pm 0 \mathrm{a}$ & $2 \pm 0 \mathrm{~cd}$ & $1 \pm 0 \mathrm{ab}$ & $2 \pm 0 \mathrm{abc}$ & $2 \pm 0 \mathrm{~d}$ & $2 \pm 0 \mathrm{bcd}$ & $2 \pm 0 \mathrm{~d}$ \\
\hline \multirow{2}{*}{$\begin{array}{c}\text { SN } \\
\text { (ten thousand } \cdot h^{-1} \text { ) }\end{array}$} & 2018-2019 & $651 \pm 43 a$ & $808 \pm 90 \mathrm{ab}$ & $791 \pm 65 \mathrm{ab}$ & $863 \pm 26 b c$ & $742 \pm 76 \mathrm{ab}$ & $887 \pm 16 b$ & $1029 \pm 57 \mathrm{c}$ & $1003 \pm 33 c$ \\
\hline & $2019-2020$ & $667 \pm 24 a$ & $811 \pm 58 b$ & $794 \pm 66 \mathrm{ab}$ & $844 \pm 21 b$ & $769 \pm 54 \mathrm{ab}$ & $901 \pm 12 b c$ & $1042 \pm 29 d$ & $993 \pm 40 \mathrm{~cd}$ \\
\hline \multirow{2}{*}{$\begin{array}{l}\text { TKW } \\
(\mathrm{g})\end{array}$} & 2018-2019 & $50.0 \pm 0.4 \mathrm{~d}$ & $50.8 \pm 0.2 \mathrm{de}$ & $51.6 \pm 0.5 \mathrm{e}$ & $52.8 \pm 0.4 \mathrm{f}$ & $41.0 \pm 0.5 \mathrm{a}$ & $44.6 \pm 0.2 b$ & $44.9 \pm 0.2 b$ & $47.3 \pm 0.4 c$ \\
\hline & $2019-2020$ & $50.6 \pm 0.2 \mathrm{~d}$ & $51.2 \pm 0.7 \mathrm{de}$ & $52.4 \pm 0.1 \mathrm{e}$ & $53.0 \pm 0.2 \mathrm{f}$ & $41.5 \pm 0.7 \mathrm{a}$ & $45.3 \pm 0.4 \mathrm{~b}$ & $45.1 \pm 0.3 \mathrm{~b}$ & $47.2 \pm 0.1 \mathrm{c}$ \\
\hline \multirow{2}{*}{$\begin{array}{c}\mathrm{GY} \\
\left(\mathrm{kg} \cdot \mathrm{ha}^{-1}\right)\end{array}$} & $2018-2019$ & $8233.9 \pm 19.7 d$ & $8382.0 \pm 61.6 \mathrm{e}$ & $8429.4 \pm 25.2 \mathrm{e}$ & $9280.8 \pm 24.9 f$ & $7001.6 \pm 41.6 \mathrm{a}$ & $7255.4 \pm 43.5 b$ & $7085.8 \pm 36.3 \mathrm{a}$ & $7431.8 \pm 65.9 \mathrm{c}$ \\
\hline & 2019-2020 & $8250.4 \pm 15.1 \mathrm{c}$ & $8344.8 \pm 154.7 \mathrm{c}$ & $8508.9 \pm 146.2 \mathrm{c}$ & $9222.3 \pm 103.3 \mathrm{~d}$ & $7024.7 \pm 55.5 \mathrm{a}$ & $7218.3 \pm 111.4 \mathrm{ab}$ & $7109.6 \pm 66.3 \mathrm{a}$ & $7508.9 \pm 74.8 b$ \\
\hline
\end{tabular}

Note: Values were represented as means \pm s.e. $(\mathrm{n}=15)$, lowercase letters indicated the significant difference among different treatments in the same row $(P<0.05)$. Letter D, N, and $\mathrm{G}$ were the treatments of sowing date, $\mathrm{N}$ basal to topdressing ratios and wheat varieties, respectively. MSSL was the main stem spike length, MSSSN was the main stem spike spikelet number, MSSGN was the main stem spike grain number, SSN was the sterile spikelet number, SN was the spike number per unit, TKW was the thousand kernel weight, GY was the grain yield.

\section{Effects of sowing date and nitrogen application on grain quality}

In the recent years, GY have been maintained with continuous growth in China. However, there has been a shortage of wheat cultivars available for high-quality grain. The $\mathrm{N}$ topdressing ration affected wheat quality and yield through the transportation and transfer of nutrients from roots to grain, with the most significant influence on the protein and processing quality (Ercoliet al., 2013). The correct $\mathrm{N}$ topdressing ratio can alleviate negative impacts of adversity stress on grain weight and protein content during grain filling period, hereby improve PC, WGC, and SV (Ahangeret al., 2019). Here, after harvest, the grain quality of different treatment groups was investigated (Table 4). Compared to the corresponding treatment of the delayed D2 sowing date, the D1 treatment groups showed an slightly increased trend in PC, HI and FY alongside a decrease in ST and SV indexs. It was reported that late sowing date helps to optimize the quality of strong gluten wheat, with the increase of PC, flour stretching resistance and the dough development time (Zhong et al., 2018; 2019). Here, the excessive late sowing time resulted in an increase in ST and SV alongside a decrease in PC and FY, probably accounting for the reduced accumulation rate of dry matter for vegetative organs at late flowering stage due to the poor population structure and low photosynthesis. Within the same sowing date and cultivar, the N1 treatment compared to the N2 showed a decrease in PC, ST, SV and FY, and an increase in HI. In addition, under the D1N2G2 treatment, PC reached the maximum value in the both seasons with an average of $15.0 \%$. Overall, the adequate basal $\mathrm{N}$ application is conducive to FY, appropriate implementation of basal to topdressing ratio of $\mathrm{N}$ fertilizer could facilitate the enhanced grain quality of bread wheat, and the adjustment of wheat source-sink relation has a potential strategies to improve GY and quality of bread wheat. 
Table 4. Grain quality of bread wheat treated with both of sowing stage and nitrogen application

\begin{tabular}{|c|c|c|c|c|c|c|c|c|c|}
\hline \multirow{2}{*}{ Quality index } & \multirow{2}{*}{ Season } & \multicolumn{8}{|c|}{ Treatments } \\
\hline & & D1N1G1 & D1N1G2 & D1N2G1 & D1N2G2 & D2N1G1 & D2N1G2 & D2N2G1 & D2N2G2 \\
\hline $\mathrm{PC}$ & 2018-2019 & $14.5 \pm 0.2 \mathrm{ab}$ & $14.6 \pm 0.3 \mathrm{ab}$ & $14.8 \pm 0.3 \mathrm{ab}$ & $14.9 \pm 0.1 \mathrm{~b}$ & $14.2 \pm 0.3 \mathrm{ab}$ & $14.1 \pm 0.1 \mathrm{a}$ & $14.4 \pm 0.3 \mathrm{ab}$ & $14.6 \pm 0.0 \mathrm{ab}$ \\
\hline$(\%)$ & 2019-2020 & $14.6 \pm 0.2 \mathrm{ab}$ & $14.7 \pm 0.1 \mathrm{ab}$ & $14.9 \pm 0.2 \mathrm{ab}$ & $15.0 \pm 0.1 \mathrm{~b}$ & $14.3 \pm 0.0 \mathrm{a}$ & $14.4 \pm 0.3 \mathrm{a}$ & $14.5 \pm 0.4 \mathrm{ab}$ & $14.8 \pm 0.1 \mathrm{ab}$ \\
\hline VW & 2018-2019 & $793.7 \pm 0.9 b$ & $804.3 \pm 2.4 \mathrm{c}$ & $793.0 \pm 2.5 b$ & $806.0 \pm 0.6 \mathrm{c}$ & $781.0 \pm 1.5 \mathrm{a}$ & $804.7 \pm 1.7 \mathrm{c}$ & $794.7 \pm 2.3 \mathrm{~b}$ & $813.0 \pm 1.2 \mathrm{~d}$ \\
\hline$\left(g \cdot \mathrm{L}^{-1}\right)$ & 2019-2020 & $796.2 \pm 2.9 \mathrm{ab}$ & $804.6 \pm 1.0 \mathrm{bc}$ & $794.8 \pm 4.4 \mathrm{ab}$ & $805.9 \pm 0.7 \mathrm{bc}$ & $780.4 \pm 6.1 \mathrm{a}$ & $800.3 \pm 7.0 \mathrm{bc}$ & $793.0 \pm 9.0 \mathrm{~b}$ & $816.0 \pm 5.8 \mathrm{~d}$ \\
\hline WGC & 2018-2019 & $31.2 \pm 0.3 \mathrm{c}$ & $28.9 \pm 0.2 \mathrm{a}$ & $31.1 \pm 0.2 b c$ & $33.0 \pm 0.2 \mathrm{~d}$ & $33.0 \pm 0.2 \mathrm{~d}$ & $30.6 \pm 0.2 b$ & $31.1 \pm 0.1 \mathrm{bc}$ & $33.3 \pm 0.1 \mathrm{~d}$ \\
\hline$(\%)$ & 2019-2020 & $31.5 \pm 0.9 \mathrm{abc}$ & $30.2 \pm 1.2 \mathrm{ab}$ & $30.8 \pm 0.9 \mathrm{ab}$ & $34.0 \pm 0.4 \mathrm{c}$ & $34.2 \pm 1.0 \mathrm{c}$ & $29.5 \pm 0.4 \mathrm{a}$ & $30.9 \pm 0.5 \mathrm{ab}$ & $32.7 \pm 1.2 \mathrm{bc}$ \\
\hline ST & 2018-2019 & $7.2 \pm 0.0 \mathrm{a}$ & $7.9 \pm 0.3 b c$ & $7.5 \pm 0.0 \mathrm{ab}$ & $8.7 \pm 0.2 \mathrm{~d}$ & $7.7 \pm 0.0 \mathrm{abc}$ & $8.3 \pm 0.3 \mathrm{~cd}$ & $8.0 \pm 0.1 b c$ & $9.3 \pm 0.1 \mathrm{e}$ \\
\hline$(\min )$ & 2019-2020 & $7.1 \pm 0.1 \mathrm{a}$ & $7.8 \pm 0.1 \mathrm{c}$ & $7.4 \pm 0.1 \mathrm{ab}$ & $8.9 \pm 0.1 \mathrm{~d}$ & $7.6 \pm 0.1 b c$ & $8.6 \pm 0.1 \mathrm{~d}$ & $7.9 \pm 0.2 \mathrm{c}$ & $9.4 \pm 0.1 \mathrm{e}$ \\
\hline DT & 2018-2019 & $3.7 \pm 0.0 \mathrm{abc}$ & $3.6 \pm 0.1 \mathrm{a}$ & $3.7 \pm 0.0 \mathrm{ab}$ & $4.2 \pm 0.0 \mathrm{~d}$ & $3.8 \pm 0.1 \mathrm{c}$ & $3.8 \pm 0.0 \mathrm{c}$ & $3.8 \pm 0.1 b c$ & $4.2 \pm 0.0 \mathrm{~d}$ \\
\hline$(\min )$ & 2019-2020 & $3.6 \pm 0.1 \mathrm{a}$ & $3.7 \pm 0.1 \mathrm{ab}$ & $3.6 \pm 0.2 \mathrm{a}$ & $4.3 \pm 0.2 \mathrm{c}$ & $3.9 \pm 0.1 \mathrm{ab}$ & $3.8 \pm 0.1 \mathrm{ab}$ & $3.9 \pm 0.1 \mathrm{ab}$ & $4.0 \pm 0.1 \mathrm{bc}$ \\
\hline $\mathrm{HI}$ & 2018-2019 & $73.7 \pm 0.3 c$ & $76.3 \pm 0.3 \mathrm{~d}$ & $72.0 \pm 0.6 b$ & $74.7 \pm 0.3 \mathrm{c}$ & $71.6 \pm 0.3 b$ & $69.7 \pm 0.3 \mathrm{a}$ & $71.0 \pm 0.6 \mathrm{~b}$ & $69.1 \pm 0.3 \mathrm{a}$ \\
\hline$(\%)$ & $2019-2020$ & $74.0 \pm 0.6 \mathrm{bc}$ & $76.9 \pm 0.6 \mathrm{~d}$ & $73.0 \pm 0.6 \mathrm{abc}$ & $74.3 \pm 1.2 \mathrm{c}$ & $71.7 \pm 0.7 \mathrm{abc}$ & $71.7 \pm 0.9 \mathrm{abc}$ & $71.3 \pm 0.9 \mathrm{ab}$ & $69.7 \pm 1.2 \mathrm{a}$ \\
\hline SV & 2018-2019 & $23.5 \pm 1.0 \mathrm{a}$ & $23.4 \pm 0.1 \mathrm{a}$ & $24.6 \pm 0.1 \mathrm{ab}$ & $27.5 \pm 0.1 \mathrm{c}$ & $25.0 \pm 0.2 \mathrm{~b}$ & $24.2 \pm 0.1 \mathrm{ab}$ & $25.2 \pm 0.1 b$ & $27.7 \pm 0.2 \mathrm{c}$ \\
\hline$(\mathrm{ml})$ & $2019-2020$ & $23.0 \pm 0.8 \mathrm{a}$ & $22.9 \pm 0.6 \mathrm{a}$ & $25.4 \pm 0.5 \mathrm{ab}$ & $27.4 \pm 1.3 \mathrm{c}$ & $25.2 \pm 0.7 \mathrm{ab}$ & $25.1 \pm 0.4 \mathrm{ab}$ & $25.5 \pm 1.1 \mathrm{ab}$ & $28.5 \pm 0.6 \mathrm{c}$ \\
\hline FY & $2018-2019$ & $65.4 \pm 0.1 \mathrm{a}$ & $67.9 \pm 0.1 \mathrm{c}$ & $65.8 \pm 0.1 \mathrm{a}$ & $68.0 \pm 0.1 \mathrm{c}$ & $65.2 \pm 0.3 \mathrm{a}$ & $66.4 \pm 0.1 \mathrm{~b}$ & $65.5 \pm 0.3 \mathrm{a}$ & $66.8 \pm 0.2 b$ \\
\hline (\%) & $2019-2020$ & $64.8 \pm 0.6 \mathrm{a}$ & $68.2 \pm 0.4 \mathrm{~cd}$ & $66.0 \pm 0.3 \mathrm{ab}$ & $68.9 \pm 0.5 \mathrm{~d}$ & $64.5 \pm 0.3 \mathrm{a}$ & $66.5 \pm 0.4 \mathrm{abc}$ & $65.7 \pm 1.3 \mathrm{ab}$ & $67.1 \pm 0.9 \mathrm{bcd}$ \\
\hline
\end{tabular}

Note: Values were represented as means \pm s.e. $(\mathrm{n}=15)$, lowercase letters indicated the significant difference among different treatments in the same row $(P<0.05)$. Letter $\mathrm{D}, \mathrm{N}$, and $\mathrm{G}$ were the treatments of sowing date, $\mathrm{N}$ basal to topdressing ratios and wheat varieties, respectively. PC was the protein content, VW was the volume weight, WGC was the wet gluten content, ST was the stability time, DT was the development time, HI was the hardness index, SV was the sedimentation value, FY was the flour yield.

\section{Evaluation of different treatments on yield-related traits \\ (I) Principal component analysis (PCA) of the agronomy traits}

Twenty-five traits under eight treatments were adopted to conduct the PCA (Table 5). The cumulative contribution rate of the first four indexes was $94.23 \%$, which represents the majority of 25 traits. The original 25 traits were streamlined into four mutually independent comprehensive indexes, defined as the first to the fourth principal component. Based on the critical value of principal component coefficient above 0.8 , there were 5 single indexes in the first principal component, 2 single indexes in the second, and none in the third and fourth. From this, it can be argued that TN, FLAN, Ci, A, PH, LAI, and FY were the key indexes to identify the phenotype variation when coordinately treated by growth years, $\mathrm{N}$ application, sowing date and wheat cultivars.

\section{(II) Subordinate function analysis and weight definition}

Subordinate function used in processing all comprehensive indexes varied among the eight treatment groups (Table 6). Take the first comprehensive index $\mathrm{CI}_{1}$ as an example: $u\left(X_{1}\right)$ index under D1N2G2 treatment was the largest (1.00), while it was the smallest under D2N2G1 treatment $(0.00)$, indicating that D1N2G2 and D2N2G1 treatment had the most and lowest significant effect on the $\mathrm{CI}_{1}$ comprehensive index, respectively. According to the contribution rate of the four comprehensive indexes in Table $5(0.51,0.25,0.11$, and 0.07$)$, the weights of the four indexes were $0.54,0.27,0.12$, and 0.08 respectively. 
Table 5. Principal component coefficient of comprehensive indexes and their contribution

\begin{tabular}{|c|c|c|c|c|c|c|c|c|c|c|c|}
\hline \multirow{2}{*}{ No. } & \multirow{2}{*}{ Traits } & \multicolumn{4}{|c|}{ Principal component coefficient } & \multirow{2}{*}{ No. } & \multirow{2}{*}{ Traits } & \multicolumn{4}{|c|}{ Principal component coefficient } \\
\hline & & $\mathbf{C I}_{1}$ & $\mathbf{C I}_{2}$ & $\mathrm{CI}_{3}$ & $\mathbf{C I}_{4}$ & & & $\mathbf{C I}_{1}$ & $\mathrm{CI}_{2}$ & $\mathrm{CI}_{3}$ & $\mathbf{C I}_{4}$ \\
\hline $\mathrm{X} 1$ & BSN & -0.93 & -0.293 & 0.07 & -0.132 & $\mathrm{X} 14$ & SSN & -0.755 & -0.237 & 0.089 & 0.578 \\
\hline $\mathrm{X} 2$ & $\mathrm{TN}$ & 0.919 & 0.352 & 0.022 & 0.15 & $\mathrm{X} 15$ & GY & 0.711 & 0.676 & 0.107 & 0.08 \\
\hline $\mathrm{X} 3$ & $E$ & -0.913 & 0.12 & 0.16 & 0.058 & X16 & TKW & 0.682 & 0.628 & -0.009 & 0.356 \\
\hline $\mathrm{X} 4$ & $g_{\mathrm{s}}$ & -0.91 & 0.195 & 0.218 & -0.017 & $\mathrm{X} 17$ & FY & 0.035 & 0.905 & -0.381 & -0.1 \\
\hline $\mathrm{X} 5$ & FLAN & 0.908 & -0.341 & 0.044 & -0.188 & $\mathrm{X} 18$ & PH & 0.384 & 0.85 & 0.15 & 0.037 \\
\hline X6 & $C i$ & 0.901 & -0.283 & -0.144 & -0.095 & X19 & $\mathrm{PC}$ & 0.404 & 0.762 & 0.373 & 0.272 \\
\hline $\mathrm{X} 7$ & A & 0.866 & -0.063 & 0.197 & 0.423 & $\mathrm{X} 20$ & VW & -0.174 & 0.746 & -0.395 & 0.19 \\
\hline $\mathrm{X} 8$ & MSSSN & -0.837 & -0.344 & -0.185 & 0.222 & $\mathrm{X} 21$ & DT & -0.47 & 0.706 & 0.344 & -0.339 \\
\hline X9 & LAI & 0.832 & -0.495 & 0.143 & -0.179 & $\mathrm{X} 22$ & ST & -0.663 & 0.698 & -0.097 & -0.111 \\
\hline $\mathrm{X} 10$ & $\mathrm{HI}$ & 0.799 & 0.278 & -0.325 & -0.288 & $\mathrm{X} 23$ & SV & -0.606 & 0.612 & 0.484 & -0.047 \\
\hline $\mathrm{X} 11$ & $\mathrm{SN}$ & -0.797 & 0.309 & -0.108 & 0.31 & $\mathrm{X} 24$ & WGC & -0.249 & 0.256 & 0.769 & -0.504 \\
\hline $\mathrm{X} 12$ & MSSGN & 0.769 & -0.106 & 0.605 & -0.108 & $\mathrm{X} 25$ & FLA & 0.439 & 0.472 & -0.67 & -0.253 \\
\hline $\mathrm{X} 13$ & MSSL & 0.762 & -0.082 & 0.462 & 0.438 & & & & & & \\
\hline & & & & & & Con & on rate $(\%)$ & 0.51 & 0.25 & 0.11 & 0.07 \\
\hline
\end{tabular}

Note: BSN was the basic seedling number, TN was the tiller number, E was the transpiration rate, $\mathrm{g}_{\mathrm{s}}$ was the stomatal conductance, FLAN was the flag leaf angle, $\mathrm{Ci}$ was the intercellular $\mathrm{CO}_{2}$ concentration, A was the photosynthetic rate, MSSSN was the main stem spike spikelet number, LAI was the leaf area index, HI was the hardness index, SN was the spike number per unit, MSSGN was the main stem spike grain number, MSSL was the main stem spike length, SSN was the sterile spikelet number, GY was the grain yield, TKW was the thousand kernel weight, FY was the flour yield, PH was the plant height, PC was the protein content, VW was the volume weight, DT was the development time, ST was the stability time, SV was the sedimentation value, WGC was the wet gluten content, and FLA was the flag leaf area.

Table 6. Value of comprehensive index and $u\left(X_{j}\right)$, and comprehensive valuation of treatments

\begin{tabular}{|c|c|c|c|c|c|c|c|c|c|c|}
\hline \multirow{2}{*}{ Treatments } & \multicolumn{4}{|c|}{ Comprehensive indexes } & \multicolumn{4}{|c|}{ Subordinate function value } & \multirow{2}{*}{$\begin{array}{c}\text { Comprehensive effect } \\
\text { value }(D)\end{array}$} & \multirow{2}{*}{ Valuation } \\
\hline & $\mathbf{C I}_{1}$ & $\mathrm{CI}_{2}$ & $\mathrm{CI}_{3}$ & $\mathrm{CI}_{4}$ & $u\left(X_{1}\right)$ & $u\left(X_{2}\right)$ & $u\left(X_{3}\right)$ & $u\left(X_{4}\right)$ & & \\
\hline D1N1G1 & 5492.95 & 6356.49 & 499.77 & 889.87 & 0.94 & 0.45 & 0.26 & 0.32 & 0.68 & 4 \\
\hline D1N1G2 & 5279.52 & 6556.21 & 516.42 & 957.49 & 0.83 & 0.58 & 0.33 & 0.61 & 0.69 & 3 \\
\hline D1N2G1 & 5175.62 & 6652.52 & 584.32 & 968.50 & 0.77 & 0.64 & 0.63 & 0.66 & 0.71 & 2 \\
\hline D1N2G2 & 5603.32 & 7239.29 & 667.77 & 1047.76 & 1.00 & 1.00 & 1.00 & 1.00 & 1.00 & 1 \\
\hline D2N1G1 & 3937.01 & 5625.37 & 467.47 & 813.93 & 0.11 & 0.00 & 0.11 & 0.00 & 0.07 & 7 \\
\hline $\mathrm{D} 2 \mathrm{~N} 1 \mathrm{G} 2$ & 3953.81 & 5855.11 & 463.22 & 885.49 & 0.12 & 0.14 & 0.09 & 0.31 & 0.13 & 6 \\
\hline D2N2G1 & 3737.36 & 5788.89 & 442.05 & 920.61 & 0.00 & 0.10 & 0.00 & 0.46 & 0.06 & 8 \\
\hline \multirow[t]{2}{*}{$\mathrm{D} 2 \mathrm{~N} 2 \mathrm{G} 2$} & 3926.46 & 6073.60 & 498.21 & 940.98 & 0.10 & 0.28 & 0.25 & 0.54 & 0.20 & 5 \\
\hline & \multicolumn{4}{|c|}{ Index weight $\left(\omega_{j}\right)$} & 0.54 & 0.27 & 0.12 & 0.08 & & \\
\hline
\end{tabular}

\section{(III) Comprehensive evaluation and cluster analysis}

Based on the weight of the four comprehensive indexes, comprehensive effect value $(D)$ on wheat agronomy traits was valuated (Table 6). The resulting D indexes of each treatment were sorted at follows: D1N2G2 > D1N2G1 > D1N1G2 > D1N1G1 > D2N2G2 > $\mathrm{D} 2 \mathrm{~N} 1 \mathrm{G} 2>\mathrm{D} 2 \mathrm{~N} 1 \mathrm{G} 1>\mathrm{D} 2 \mathrm{~N} 2 \mathrm{G} 1$, indicating that the appropriately early sowing date and adequately basal fertilizer were essential to achieve high yield and improve grain quality. Of these treatments, D1N2G2 performed the best followed by D1N2G1, whilst the rest showed minor alterations. 8 treatment factors were divided into 3 categories where the Euclidean distance is equal to 5 (Figure3): D1N2G2 was labelled Class I with highest evaluation level, while D1N1G1, D1N1G2 and D1N2G1 labelled Class II with an average level, and D2N1G1, D2N1G2, D2N2G1 and D2N2G2 labelled Class III with the relatively lowest level. These suggested that the agronomic traits after D1N2G2 treatment were the best alterations, which was in consistency with the PCA assessment.

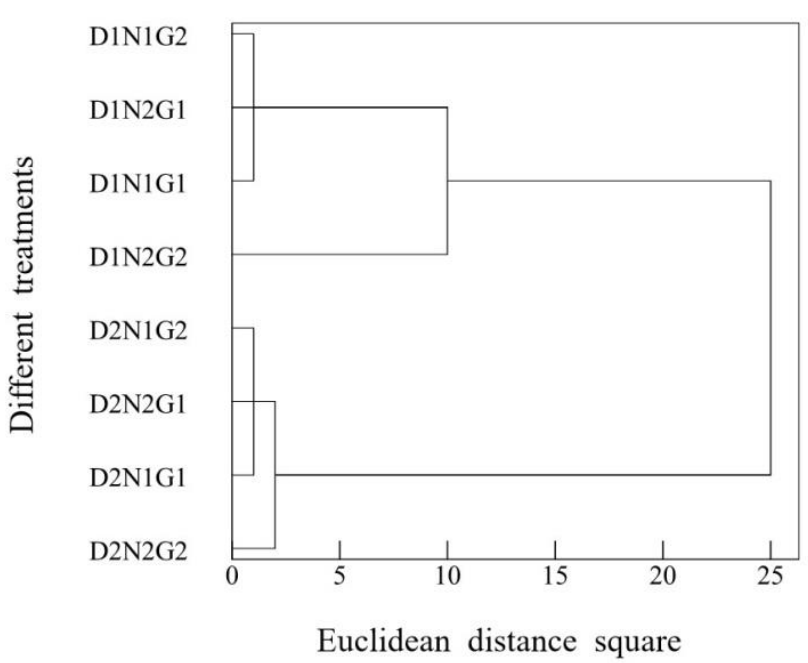

Figure3. Cluster analysis of different treatments.

Note: The different treatments were represented as DNG number. Letter $\mathrm{D}, \mathrm{N}$, and $\mathrm{G}$ were the treatments of sowing date, $\mathrm{N}$ basal to topdressing ratios and wheat varieties, respectively, the details were as Materials and Methods. 


\section{CONCLUSION}

This study highlighted that the great variation in thousand kernel weight (TKW) was a consequence of sowing date and $\mathrm{N}$ application, and the alternated spike number per unit (SN) for increase of topdressed $\mathrm{N}$. The adequate basal $\mathrm{N}$ application is conducive to flour yield (FY), and appropriate implementation of basal to topdressing ratio of $\mathrm{N}$ fertilizer could facilitate the enhanced grain quality. These results indicated that excessively delayed sowing date and high $\mathrm{N}$ topdressing ratios severely affected the canopy structure and TKW of bread wheat, and subsequently reduced economics yield and grain quality, and sowing date had a great determination on the wheat agronomic traits, leading to the prominent yield variation. The most significant positive effect on yield and quality was achieved when sowing date of wheat in the Jianghuai region was around 25 October with the $\mathrm{N}$ basal to topdressing ratio of $7: 3$, this cultivation technique is recommended to adopt along the Jianghuai region to improve economic and social conditions associated with high-efficiency wheat production.

\section{ACKNOWLEDGMENTS}

This work was financially supported by the National Key Research and Development Program of China (2018YFD0300902; 2017YFD0301301), Outstanding Talents Program of University (gxyq2020039), the Open Fund of National Engineering Laboratory of Crop Stress Resistance Breeding (NELCOF20190106), and Talents Introduced Fund of Anhui Science and Technology University (NXYJ201604).

\section{LITERATURE CITED}

Ahanger, M.A., C. Qin, N. Begum, Q. Maodong, X.X. Dong, M. El-Esawi, M.A. El-Sheikh, A.A. Alatar and L.X. Zhang. 2019. Nitrogen availability prevents oxidative effects of salinity on wheat growth and photosynthesis by up-regulating the antioxidants and osmolytes metabolism, and secondary metabolite accumulation. BMC Plant Biology 19(1): 479.

Ahmed, M. and F.U. Hassan. 2015. Response of Spring Wheat (Triticumaestivum L.) Quality Traits and Yield to Sowing Date. PLoS one 10, e0126097.

Aljarrah, M., L. Oatway, S. Albers and C. Bergen. 2014. Variability, Heritability and Genetic Advance in Some Agronomic and Forage Quality Characters of Spring Triticale in Western Canada. Communications in Agricultural and Applied Biological Sciences 79(4): 9-18.

Assefa, Y., P.V.V. Prasad, P. Carter, M. Hinds, G. Bhalla, R Schon and I.A. Ciampitti. 2017. A New Insight into Corn Yield: Trends from 1987 through 2015. Crop Science 57(5): 2799-2811.

Ayranci, R. 2020. Yield performances of winter wheat (T. aestivum) genotypes improved for dry environmental region of turkey. Turkish Journal of Field Crops 25(1): 74-82.

Barraclough, P.B. and R.A. Leigh. 1984. The growth and activity of winter wheat roots in the the field: Nutrient uptakes of high-yielding crops. Journal of Agricultural Science 103(1): 59-74.
Ercoli, L., A. Masoni, S. Pampana, M. Mariotti and I. Arduini. 2013. As durum wheat productivity is affected by nitrogen fertilisation management in Central Italy. European Journal of Agronomy 44: 38-45.

Gorczyca, A., A. Oleksy, D. Gala-Czekaj, M. Urbaniak, M. Laskowska, A. Waskiewicz and L. Stepien. 2017. Fusarium head blight incidence and mycotoxin accumulation in three durum wheat cultivars in relation to sowing date and density. Science of Nature 105(2):1-11.

Gourevitch, J., B. Keeler and T. Ricketts. 2018. Determining socially optimal rates of nitrogen fertilizer application. Agriculture Ecosystems \& Environment 254: 292-299.

Guo, B.B., B.C. Liu, L. He, Y.Y. Wang, W. Feng, Y.J. Zhu, N.Y. Jiao, C.Y. Wang and T.C. Guo. 2019. Root and nitrate-N distribution and optimization of $\mathrm{N}$ input in winter wheat. Scientific Reports 9(1): 18018.

Herrera, J.M., L. Haner, L.F. Mascher, J. Hiltbrunner, D. Fossati, C. Brabant, R. Charles and D. Pellet. 2020. Lessons From 20 Years of Studies of Wheat Genotypes in Multiple Environments and Under Contrasting Production Systems. Frontiers in Plant Science 10: 1745.

Kucharik, C.J., T. Ramiadantsoa, J. Zhang and A.R. Ives. 2020. Spatiotemporal trends in crop yields, yield variability, and yield gaps across the USA. Crop Science 60(2): 1-17.

Lu, Y.Y., W. Sun, W.A. Tang, D.Y. He and H.Q. Deng. 2020. Climatic potential productivity and stress risk of winter wheat under the background of climate change in Anhui Province. Chinese Journal of Eco-Agriculture 28(1): 17-30.

Ma, Geng., W.X. Liu, S.S. Li, P.P. Zhang, C.Y. Wang, H.F. Lu, L.F. Wang, Y.X. Xie, D.Y. Ma and G.Z. Kang. 2019. Determining the Optimal N Input to Improve Grain Yield and Quality in Winter Wheat With Reduced Apparent N Loss in the North China Plain. Frontiers in Plant Science 10: 181.

Ma, S.C., T.C. Wang, X.K. Guan and X. Zhang. 2018. Effect of sowing time and seeding rate on yield components and water use efficiency of winter wheat by regulating the growth redundancy and physiological traits of root and shoot. Field Crops Research 221: 166-174.

Mantilla-Perez, M.B. and M.G. Salas-Fernandez. 2017. Differential manipulation of leaf angle throughout the canopy: current status and prospects. Journal of Experimental Botany 68(21): 5699-5717.

Nehe, A.S., S. Misra, E.H. Murchie, K. Chinnathambi and M.J. Foulkes. 2018. Genetic variation in N-use efficiency and associated traits in Indian wheat cultivars. Field Crops Research 225: 152-162.

Song, Q.H., C.Y. Liu, B.D. Goudia, L. Chen and Y.G. Hu. 2017. Drought resistance of new synthetic hexaploid wheat accessions evaluated by multiple traits and antioxidant enzyme activity. Field Crops Research 210: 91-103.

Tilman, D., C. Balzer, J. Hill and B.L. Befort. 2011. Global food demand and the sustainable intensification of agriculture. Proceedings of the National Academy of Sciences of the United States of America 108: 20260-20264.

Zadoks, J.C., T.T. Chang, C.F. Konzak. 1974. A decimal code for the growth stages of cereals. Weed Research 14: 415-421.

Zheng, J.C., T Liu, Q.X. Zheng, J.Q. Li, Y.C. Qian, J.C. Li and Q.W. Zhan. 2020a. Identification of Cold Tolerance and Analysis of Genetic Diversity for Major Wheat Varieties in Jianghuai Region of China. Pakistan Journal of Botany 52(3): 839-849.

Zheng, J.C., Z.Y. Yang, P.J. Madgwick, E. Carmo-Silva, M.A.J. Parry and Y.G. Hu. 2015. TaER Expression is associated 
with transpiration efficiency traits and yield in bread wheat. PLoS one 10:e128415.

Zheng, X.J., Z.W. Yu, Y.L. Zhang and Y. Shi. 2020b. Nitrogen supply modulates nitrogen remobilization and nitrogen use of wheat under supplemental irrigation in the North China Plain. Scientific Reports 10: 3305.

Zhong, Y.X., D.C. Xu, K.H. Hebelstrup, D.L. Yang, J. Cai, X. Wang, Q. Zhou, W.X. Cao, T.B. Dai and D.Jiang. 2018. Nitrogen topdressing timing modifies free amino acids profiles and storage protein gene expression in wheat grain. BMC Plant Biology 18(1): 353.

Zhong, Y.X., W.L. Wang, X. Huang, M.M. Liu, K.H. Hebelstrup, D.L. Yang, J. Cai, X. Wang, Q. Zhou, W.X. Cao, T.B. Dai and D. Jiang. 2019. Nitrogen topdressing timing modifies the gluten quality and grain hardness related protein levels as revealed by iTRAQ. Food Chemistry 277: 135-141.

Zorb, C., U. Ludewig and M.J. Hawkesford. 2018. Perspective on Wheat Yield and Quality with Reduced Nitrogen Supply. Trends in Plant Science 23(11): 1029-1037. 